\title{
PENERAPAN MODEL PEMBELAJARAN KOOPERATIF TIPE SNOWBALL THROWING UNTUK MENINGKATKAN HASIL BELAJAR IPS SISWA KELAS VI SDN CIBENTANG KECAMATAN KRAMATMULYA KABUPATEN KUNINGAN
}

\author{
Roheni, S. Pd. SD. \\ SDN Cibentang
}
Pengutipan: Roheni. (2019). Penerapan model pembelajaran kooperatif tipe snowball throwing untuk meningkatkan hasil belajar IPS siswa Kelas VI SD N Cibentang Kecamatan Kramatmulya Kabupaten Kuningan. Pedagogi: Jurnal Penelitian Pendidikan, 6 (1), hlm 41-47.

Diajukan: 22-04-2019

Diterima: 30-05-2019

Diterbitkan: 31-05-2019

\begin{abstract}
ABSTRAK
Penelitian Tindakan Kelas yang dilakukan ini untuk mengupayakan perbaikan pelaksanaan pembelajaran IPS di kelas VI SDN Cibentang Kecamatan Kramatmulya Kabupaten Kuningan. Tujuannya untuk memperbaiki dan meningkatkan kualitas pembelajaran secara berkesinambungan dengan mengangkat judul "Model Pembelajaran Snowball Throwing Untuk Meningkatkan Hasil Belajar IPS Siswa Kelas VI Sekolah Dasar Cibentang Kecamatan Kramatmulya Kabupaten Kuningan”. Pelaksanan Penelitian Tindakan Kelas ini dilaksanakan di SDN Cibentang Kecamatan Kramatmulya Kabupaten Kuningan. Adapun Subjek Penelitian Tindakan Kelas ini adalah seluruh siswa kelas VI SDN Cibentang Kecamatan Kramatmulya Kabupaten Kuningan.Penelitian ini berlangsung pada tanggal 22 Januari 2018 s/d 19 februari 2018, karena waktu ini diperkirakan untuk memberikan materi tentang gejala alam dan merupakan waktu awal semester, sehingga penelitian ini tidak banyak terganggu oleh kegiatan lainnya dan dapat terlaksana sesuai jadwal. Terdiri dari Observasi Guru, Observasi Kegiatan Siswa, Tes, dan Wawancara. Setelah melakukan penelitian dengan siklus I dan II dalam pembelajaran IPS di kelas VI SDN Cibentang Kecamatan Kramatmulya Kabupaten Kuningan terlihat ada perubahan, baik dalam aktivitas guru waktu mengajar yang diperlihatkan dalam siklus ke satu sampai ke dua nampak ada perubahan, begitupun dengan aktivitas siswa.
\end{abstract}

Kata Kunci: Model Pembelajaran Kooperatif Tipe Snowball Throwing, Hasil Belajar, IPS 
Roheni, S. Pd. SD.

Penerapan Model Pembelajaran Kooperatif Tipe Snowball Throwing untuk Meningkatkan

Hasil Belajar IPS Siswa Kelas VI SD N Cibentang Kecamatan Kramatmulya Kabupaten

Kuningan

\section{PENDAHULUAN}

Guru merupakan agen pendidikan serta berbagai kunci keberhasilan dan sekaligus ujung tombak pencapaian misi perubahan pendidikan, para guru berada di titik sentral untuk mengatur, mengerahkan dan menciptakan suasana pembelajaran yang aktif inovatif, kreatif, efektif, yang menyenangkan bagi siswa sehingga dapat mencapai tujuan pembelajaran yang diharapakan dan sesuai dengan tujuan pendidikan nasional. Oleh karena itu, guru dituntun lebih profesional, inovatif dan kreatif dalam melaksanakan tugas pembelajarannya. Monotonnya metode atau media yang digunakan oleh guru dapat menimbulkan kejenuhan bagi siswa dalam pembelajaran yang pada akhirnya dapat menurunkan motivasi,minat belajar siswa serta prestasi belajar jauh dari apa yang diharapkan. Dari kondisi tersebut jelaslah bahwa proses pembelajaran tersebut tidak dapat meningkatkan prestasi belajar siswa dalam proses pembelajaran.

Berdasarkan pengamatan yang dapat dilakukan pada saat proses pembelajaran IPS berlangsung di kelas VI SDN Cibentang Kecamatan Kramatmulya Kabupaten Kuningan sampai saat ini kurang berhasil meningkatkan motivasi,minat belajar dan berpikir kritis di kalangan siswa. Dengan melihat kesenjangan di atas, sebenarnya usaha untuk meningkatkan kualitas pembelajaran IPS sudah banyak dilakukan, baik melalui seminar, penataran, maupun pertemuan gugus sekolah. Salah satu cara yang dapat dilakukan guru untuk meningkatkan pembelajaran IPS dengan penggunaan metode dan sumber belajar dalam istilah lain menggunakan model pembelajaran karena model pembelajaran merupakan prosedur sistematis dalam mengorganisasikan pengalaman belajar untuk mencapai tujuan belajar, sebagaimana diungkapakan oleh Toeti Soekamto dan Winataputra (1995: 78) mendefinisikan "Model pembelajaran sebagai kerangka konseptual yang menggambarkan prosedur yang sistematis dalam mengorganisasikan pengalaman belajar bagi para siswa untuk mencapai tujuan pembelajaran dan berfungsi sebagai pedoman bagi para perancang pembelajaran dan para pengajar dalam merencanakan dan melaksanakan aktivitas belajar mengajar".

Berdasarkan beberapa pandangan dan permasalahan di atas penulis beranggapan perlu diadakan Penelitian Tindakan Kelas yang mengupayakan perbaikan pelaksanaan pembelajaran IPS di kelas VI SDN Cibentang Kecamatan Kramatmulya Kabupaten Kuningan. Tujuannya untuk memperbaiki dan meningkatkan kualitas pembelajaran secara berkesinambungan dengan menggunakan "Model Pembelajaran Snowball Throwing Untuk Meningkatkan Hasil Belajar IPS Siswa Kelas VI Sekolah Dasar Cibentang Kecamatan Kramatmulya Kabupaten Kuningan".

\section{METODE PENELITIAN}

Penelitian ini merupakan Penelitian Tindakan Kelas (Class Action Research) menggunakan Model Pembelajaran Kooperatif Tipe Snowball Throwing untuk Meningkatkan Hasil Belajar Ilmu Pengetahuan Sosial (IPS) Siswa Kelas VI Sekolah Dasar Cibentang Kecamatan Kramatmulya Kabupaten Kuningan.Pelaksanan Penelitian Tindakan Kelas ini dilaksanakan di SDN Cibentang Kecamatan Kramatmulya Kabupaten Kuningan.Subjek Penelitian Tindakan Kelas ini adalah seluruh siswa kelas VI SDN Cibentang Kecamatan Kramatmulya Kabupaten Kuningan.

Penelitian ini berlangsung pada tanggal 22 Januari 2018 s/d 19 februari 2018, karena waktu ini diperkirakan untuk memberikan materi tentang gejala alam dan merupakan waktu awal semester, sehingga penelitian ini tidak banyak terganggu oleh kegiatan lainnya dan dapat terlaksana sesuai jadwal. Teknik pengumpulan data terdiri dari Observasi Guru, Observasi Kegiatan Siswa, Tes, dan Wawancara.

Observasi adalah semua kegiatan siswa yang ditujukan untuk mengamati, merekam, dan mendokumentasikan setiap indikator dari proses dan hasil yang dicapai baik yang ditimbulkan 
oleh tindakan yang terencana maupun akibat sampingannya.Pada kegiatan observasi, peneliti menggunakan pedoman observasi yang berbentuk format isian, peneliti sebagai pengamat hanya memberikan atau membubuhkan tanda centang $(\sqrt{ })$ pada aspek yang muncul. Lembar observasi siswa yang digunakan untuk mengumpulkan data tentang keaktifan, partisipasi, motivasi dan kerjasama siswa pada kegiatan awal, inti, dan akhir selama pembelajaran berlangsung. Lembar observasi kegiatan siswa diisi oleh peneliti ketika sedang melaksanakan perbaikan. Selain untuk mendapatkan data kealitatif, hasil observasi kegiatan siswa ini juga dapat digunakan sebagai penilaian untuk didiskusikan dengan supervisor. Selain menentukan aspek yang diamati peneliti juga mendiskusikan indicator-indikator keberhasilan pada penilaian kinerja tersebut.

Depdiknas, (2003: 32) pengertian tes hasil belajar adalah "Tes prestasi belajar yang disusun oleh guru untuk mengukur hasil pembelajaran atau kemajuan belajar murid".Untuk memperoleh data hasil tentang kemampuan siswa dalam pemahaman terhadap pembelajaran IPS tentang gejala alam kelas VI SDN Cibentang. Alat tes hassil belajar ini berupa tes tertulis dalam jawaban singkat. Menurut Nasution (1966: 69) mengemukakan bahwa observasi saja tidak memadai dalam melakukan penelitian itu sebabnya observasi harus dilengkapi oleh wawancara. Dengan melakukan wawancara peneliti dapat memasuki dunia pikiran dan perasaan siswa.

Untuk menunjang keberhasilan suatu metode yang digunakan dibutuhkan teknik penelitian. Arikunto (1998: 159) berpendapat bahwa teknik adalah langkah-langkah yang harus dilakukan peneliti di lapangan pada saat melakukan penelitian ini adalah: (a) Teknik analisis hasil obsevasi; (b) Teknik analisis hasil data tes; (c) Teknik analisis data hasil wawancara. Untuk menganalisis tingkat keberhasilan atau persentase keberhasilan siswa setelah proses belajar mengajar setiap putarannya dilakukan dengan wawancara memberikan evaluasi berupa tugas mengajar pada setiap akhir putaran.

\section{HASIL PENELITIAN DAN PEMBAHASAN}

Pada bagian ini dideskripsikan mengenai hasil penelitian dan pembahasan dalam mata pelajaran IPS. Untuk lebih jelas dapat dilihat pada data di bawah ini.

Tabel 1. Perencanaan Pelaksanaan Pembelajaran Siklus I

\begin{tabular}{clc} 
No. & \multicolumn{1}{c}{ Kegiatan } & Keterangan \\
\hline $\mathbf{1}$ & Diskusi dengan teman sejawat dan membuat RPP & 22 Januari 2018 \\
\hline $\mathbf{2}$ & Pelaksanaan siklus ke satu mata pelajaran IPS & 29 Januari 2018 \\
\hline $\mathbf{3}$ & $\begin{array}{l}\text { Materi pembelajaran menjelaskan tentang gejala } \\
\text { alam }\end{array}$ & $\begin{array}{c}\text { Metode Tanya } \\
\text { jawab, penugaan dan } \\
\text { diskusi }\end{array}$ \\
\hline
\end{tabular}

4 Kliping gejala alam sebagai sumber belajar

Sebelum guru memulai pelajaran, guru melakukan apersepsi dengan Tanya jawab mengenai gejala alam. Contohnya, "Gejala alam apakah yang pernah kalian alami?" demikian tanya jawab yaqng dilakukan oleh guru dengan memperlihatkan gambar-gambar gejala alam. Perhatian siswa pada pembelajaran ini. Perhatian siswa pada pelajaran ini kurang lebih $60 \%$ siswa yang masih terbiasa dengan pembelajaran biasa kurang lebih $40 \%$.

Setelah apersepsi, guru menyampaikan tujuan dan langkah yang akan ditempuh, guru memasang gambar-gambar gejala alam lalu mengadakan tanya jawab. Guru memanggil ketuaketua kelompok untuk membagi tugas. Ketua kelompok kembali ke kelompoknya untuk bersama-sama melaksanakan tugas. Guru membagikan selembar kertas pada setiap siswa agar diisi satu buah pertanyaan tentang materi yang dipelajarinya. Kertas diremas-remas dijadikan bola lalu dilempar sesama teman. Setelah mendapat satu bola, siswa lalu menjawabnya. Guru mengadakan persentasi kelas dengan memanggil wakil dari kelompok, diskusi kelas membahas 
Roheni, S. Pd. SD.

Penerapan Model Pembelajaran Kooperatif Tipe Snowball Throwing untuk Meningkatkan

Hasil Belajar IPS Siswa Kelas VI SD N Cibentang Kecamatan Kramatmulya Kabupaten

Kuningan

hasil siswa. Siswa bersama guru menyimpulkan hasil pembelajaran. Untuk mengetahui kemampuan siswa dalam proses pembelajaran dengan menggunakan model Snowball Throwing guru melakukan evaluasi.

Dari deskripsi analisis refleksi siklus ke satu, dapat disimpulkan sebagai berikut: (a) Kegiatan guru tidak menggunakan satu metode, terlihat guru belum terbiasa dengan multi metode; (b) Siswa terlihat aktif dalam proses pembelajaran; (c) Ketika siswa saling melempar bola salju terlihat sangat senang dan termotivasi untuk segera menjawabnya; (d) Siswa belum terbiasa dengan model pembelajaran seperti ini, diskusinya masih dikuasai anak yang lebih pintar, dan masih kaku dalam presentasi di depan kelas; (d) Guru telah menjadi fasilitator dalam proses pembelajaran ini; (e) Rata-rata kelas hasil evaluasi pada siklus satu adalah 69,7, hal ini memperlihatkan ada perubahan dari hasil sebelum perbaikan proses pembelajaran, namun masih ada beberapa orang siswa yang nilainya di bawah KKM.

Rencana pengembangan perbaikan sebagai langkah selanjutnya yaitu: (a) Guru tetap menggunakan model pembelajaran Snowball Throwing; (b) Untuk meningkatkan proses pembelajaran yang terpusat pada siswa, guru akan menugaskan siswa untuk membuat kliping tentang gejala alam; (c) Siswa akan tetap melakukan pembelajaran kelompok dan melakukan presentasi di depan kelas, dengan tujuan melatih keberanian siswa; (d) Materi pada siklus ke dua lebih dikhususkan ke gejala alam di Indonesia dan Negara tetangga; (e) Tindakan siklus ke dua akan dilaksanakan tanggal 19 Januari 2018.

Tabel 2. Perencanaan Pelaksanaan Pembelajaran Siklus II

\begin{tabular}{clc}
\hline No. & \multicolumn{1}{c}{ Kegiatan } & \multicolumn{1}{c}{ Keterangan } \\
\hline $\mathbf{1}$ & Diskusi dengan teman sejawat dan membuat RPP & 29 Januari 2018 \\
\hline $\mathbf{2}$ & Pelaksanaan siklus ke satu mata pelajaran IPS & 5 Februari 2018 \\
\hline $\mathbf{3}$ & $\begin{array}{l}\text { Materi pembelajaran menjelaskan tentang gejala } \\
\text { alam }\end{array}$ & $\begin{array}{c}\text { Metode / Model } \\
\text { Snowball Throwing }\end{array}$ \\
\hline $\mathbf{4}$ & Kliping gejala alam sebagai sumber belajar & \\
\hline
\end{tabular}

Pelaksanaan tindakan siklus II sebagai berikut: (a) Mengkondisikan siswa pada situasi yang kondusif; (b) Guru menyampaikan apersepsi dengan memberikan beberapa pertanyaan, yaitu: Sebutkan jenis-jenis gejala alam!, atau Mengapa terjadi banjir?; (c) Guru menyampaikan tujuan pembelajaran dan langkah yang akan ditempuh; (d) Guru mengelompokkan siswa; (e) Siswa menyimak penjelasan guru tentang gejala alam di Indonesia dan Negara tetangga; (f) Guru-guru memanggil ketua-ketua kelompok untuk diberi tugas; (g) Siswa dalam kelompok membahas materi yang ditugaskan; (h) Siswa dibagi selembar kertas untuk membuat pertanyaan dari materi yang dipelajarinya; (i) Siswa saling melempar bola salju; (j) Siswa menjawab pertanyaan; (k) Siswa wakil kelompok mempresentasikan jawabannya; (l) Diskusi kelas membahas hasil siswa, guru memberi penguatan; $(\mathrm{m})$ Siswa bersama guru menyimpulkan hasil pembelajaran; (n) Siswa menyelesaikan evaluasi; (o) Guru memberikan tindak lanjut dengan memberikan penugasan mencari berita tentang gejala alam di negara lain. Pada pembelajaran siklus ke dua banyak sekali perubahan yang tadinya hanya asal-asalan sudah mulai terarah, bahwa itulah pembelajaran bukan mainan.

Dari deskripsi siklus ke dua, dapat disimpulkan sebagai berikut: (a) Guru mulai terbiasa menggunakan model pembelajaran; (b) Dalam proses pembelajaran ini guru menjadi fasilitator dan bukan satu-satunya sebagai informasi; (c) Siswa terlihat aktif, pembelajaran berpusat pada siswa; (d) Siswa mulai terbiasa dengan diskusi; (e) Untuk hasil evaluasi setiap siklus sangat berbeda, pada siklus ke dua nilai rata-rata kelas adalah 88,33. Hal ini merupakan hasil yang sangat memuaskan dibandingkan dengan siklus ke satu; (f) Pembelajaran dengan menggunakan model Snowball Throwing dapatmeningkatkan motivasi, kreatifitas, aktivitas dan hasil belajar siswa. 
Pada bagian ini akan dibahas mengenai pertanyaan penelitian yang menyangkut: Pembelajaran dengan menggunakan model pembelajaran Snowball Throwing dapat meningkatkan hasil belajar siswa pada pelajaran IPS." Berdasarkan analisis dan temuan empiris pada setiap pembelajaran IPS, dapat dibahas temuan-temuan sebagai berikut:

Pada siklus ke satu pembelajaran IPS di kelas VI SDN Cibentang hasil belajarnya belum memuaskan, dalam pembelajaran tersebut dapat dilihat sebagai berikut: (a) Guru belum terbiasa dengan pembelajaran yang menggunakan multi metode; (b) Siswa masih kurang aktif dalam pembelajaran kelompok; (c) Siswa masih ada yang menggunakan model pembelajaran ini untuk main-main; (d) Hasil evaluasi ada kemajuan dibandingkan sebelum perbaikan.

Pada siklus ke dua Nampak ada perubahan dalam pembelajaran, hal ini dapat dilihat di bawah ini: (a) Guru mulai terbiasa menggunakan model pembelajaran multimedia; (b) Siswa nampak aktif dalam proses pembelajaran; (c) Guru menjadi pembimbing dan fasilitator; (d) Siswa mengikuti proses pembelajaran dengan sungguh-sungguh; (e) Ada peningkatan yang signifikan dalam perolehan hasil belajar siswa.

Setelah melakukan perbaikan dalam pembelajaran IPS di kelas VI SDN Cibentang Kecamatan Kramatmulya Kabupaten Kuningan terlihat ada perubahan, baik dalam aktivitas guru waktu mengajar yang diperlihatkan dalam siklus ke satu sampai ke dua nampak ada perubahan, begitupun dengan aktivitas siswa. Hal tersebut dapat terlihat pada grafik di bawah ini.

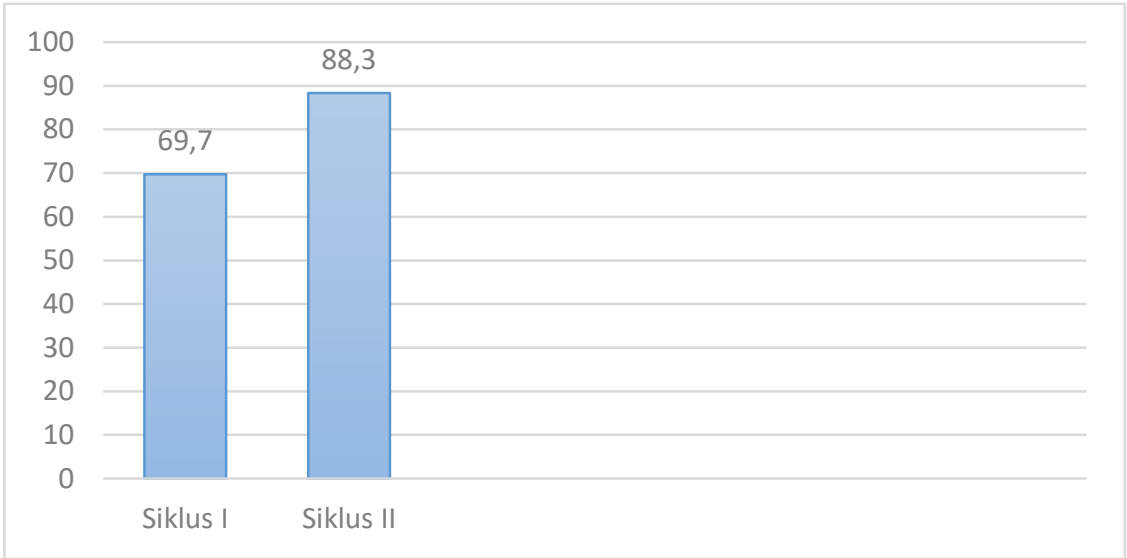

Gambar 1. Grafik Perolehan Nilai Siklus Ke-1 dan Ke-2 Mata Pelajaran IPS

\section{SIMPULAN DAN SARAN}

Simpulan

Kebermaknaan proses pembelajaran model Snowball Throwing pada mata pelajaran IPS diperoleh sebagai berikut: Model pembelajaran Snowball Throwing pada mata pelajaran IPS di sekolah dasar dapat merangsang peningkatan hasil belajar siswa pada pembelajaran serta mampu memcahkan masalah dalam kehidupan nyata, dan diharapkan dalam pembelajaran yang menggunakan model Snowball Throwing dapat meningkatkan hasil belajar siswa pada mata pembelajaran lain.

Saran

Sebagai saran dari hasil penelitian ini, dikemukakan beberapa saran yang diharapkan dapat memberikan subangan pemikiran dalam upaya perbaikan kegiatan pembelajaran di Sekolah Dasar khususnya model pembelajaran Snowball Throwing sebagai berikut: (a) Bagi Guru Sekolah Dasarproses dan hasil belajar tentang penggunaan model Snowball Throwing pada pembelajaran IPS dapat mengembangkan kemampuan dalam melakukan tindakan perbaikan serta meningkatkan proses hasil belajar, serta guru diharapkan lebih aktif dan kreatif dalam menggunakan model pembelajaran; (b) Hasil penelitian ini diharapkan dapat dijadikan salah satu masukan bagi UPTD SD yang ada di Kecamatan Kramatmulya Kabupaten Kuningan 
Roheni, S. Pd. SD.

Penerapan Model Pembelajaran Kooperatif Tipe Snowball Throwing untuk Meningkatkan Hasil Belajar IPS Siswa Kelas VI SD N Cibentang Kecamatan Kramatmulya Kabupaten Kuningan

dalam meningkatkan kinerja guru dan membenahi proses pembelajaran khususnya pembelajaran IPS di sekolah dasar, sebaiknya diperbanyak pelatihan guru mengenai modelmodel pembelajaran yang berpusat pada siswa (Student Center). 


\section{DAFTAR PUSTAKA}

Asmawi Zainul \& Agus Mulyana. (2007). Tes dan assessment di SD. Jakarta: Universitas Terbuka.

Dahar, Ratna Wilis. (1996). Teori-teori belajar. Jakarta: Erlangga.

Hera Lestari Mikarta, dkk. (2007). Pendidikan anak di SD. Jakarta: Universitas Terbuka.

Indrastuti, Penny Rahmawaty. (2008). Ilmu pengetahuan sosial kelas VI. Jakarta: Pusat Perbukuan Departemen Pendidikan Nasional.

Juliansyah Noor. (2011). Metodologi penelitian. Jakarta: Kencana.

Moh Nazir. (2011). Metode penelitian. Bogor: Ghalia Indonesia.

Nana Bermana, dkk. (2007). Ilmu pengetahuan sosial VI. Bandung: SPKN.

https://muhammadanshari9.blogspot.com/2013/10/model-pembelajaran-snowballthrowing.html

https://proposalmatematika23.blogspot.com/2013/05/model-pembelajaran-snowballthrowing.html

Wardani, I.G.A.K, dkk. (2007). Penelitian tindakan kelas. Jakarta: Universitas Terbuka. 